\title{
MULTIMODAL ULTRASONIC DIAGNOSIS AT THE TREATMENT OF RENAL CELL CARCINOMA WITH THE INTRALUMINAL VENOUS INVASION INTO INFERIOR VENA CAVA SYSTEM
}

\author{
Yulia A. Stepanova*, Olesya A. Chekhoeva, Viktoriya A. Kopacheva, \\ Vlada Yu. Raguzina, Madina Kadyrova, Alexander A. Gritskevich, Tatiana P. Baytman, \\ Irina V. Miroshkina, Zholboldu Polotbek uulu, Alina A. Chevina, Alexander A. Teplov
}

\author{
A.V. Vishnevsky National Medical Research Center of Surgery, Moscow, Russian Federation
}

\begin{abstract}
The aim is to study the possibilities of ultrasound diagnostics used in assessing the prevalence of the tumor process, its structure, and the degree of fixation or ingrowth of the tumor thrombus into the venous wall. The research was conducted in the Urological Department of the A.V. Vishnevsky National Medical Research Center of Surgery. 41 patients suffering from RCC complicated by the intraluminal venous invasion into the renal vein and/or IVC aged $39-80$ years were treated. 15 women and 26 men took part in the research. The level of thrombus spreading, the extent of its fixation and ingrowth inside the vascular wall, its structure and vascularization are of major importance for the planning of operation technique and predicting treatment outcomes. An algorithm for evaluating a tumor thrombus during ultrasound examination was developed based on the analysis of data from patients with RCC with renal and/or IVC tumor invasion. The presented algorithm of ultrasound examination allows us to determine the level of spread, structure and possible invasion of a tumor thrombus most accurately, thereby determining the volume of surgical intervention and, in some cases, leading to its reduction.
\end{abstract}

Key words: Diagnostics, neoplastic venous thrombosis, renal cell carcinoma, surgery, ultrasound

\section{INTRODUCTION}

Renal cell carcinoma (RCC) is the most common primary renal tumor. RCC takes about $4 \%$ of all malignant neoplasms in the adult population in Russia. One of the most special features of RCC is its frequent spread through the venous system: it spreads into the renal vein in $25-30 \%$ of cases, into the inferior vena cava (IVC) in $4-10 \%$ of cases, and in $1 \%$ of cases into the right atrium [1-5]. In some cases, there is a retrograde spread of the thrombus along the lumen of IVC, which often has a vascular origin and is represented by thrombi $[6,7]$.

Currently, nephrectomy with thrombectomy is the only type of treatment that has a significant beneficial effect on the life expectancy of patients suffering from RCC complicated by IVC tumor thrombosis. The radicality of the operation is a reliable prognostic sign positively affecting survival. The five-year disease-free survival rate among the patients undergoing nephrectomy and thrombectomy for RCC complicated by tumor thrombosis is $58.3 \%$ [8]. The isolation within a certain section of IVC is one of the main aims of this intervention, since there is a high risk of the thrombus fragmentation and, as a consequence, the development of pulmonary embolism. Therefore, the definition of the level the thrombus spread into IVC lumen is especially important for the determination of the tactics of surgical intervention $[5,9,10]$.
The rupture of a thrombus is one of the most dangerous complications of such a surgical intervention. The structure of a thrombus is the main criteria that determine the risk of thrombus rupture during surgery. This complication is especially typical for the thrombi of dense or loose consistency [11, 12].

$$
\text { 2. AIM }
$$

The aim is to study the possibilities of ultrasound diagnostics used in assessing the prevalence of the tumor process, its structure, and the degree of fixation or ingrowth of the tumor thrombus into the venous wall.

\section{MATERIAL AND METHODS}

The research was conducted in the Urology Department of the A.V. Vishnevsky National Medical Research Center of Surgery. 41 patients suffering from RCC complicated by the invasion into the renal vein and/or IVC aged 39 - 80 years were treated. 15 women and 26 men took part in the research. All the patients underwent ultrasound (US) examination in B-mode and duplex scanning. The US with Sonovue contrast enhancement was implemented if the thrombus spread to IVC. Three-dimensional reconstruction was also carried out for medical reasons. A contrast-enhanced multidetector computed tomography (MDCT) and/or

\footnotetext{
*stepanovaua@mail.ru
} 
Yu.A. Stepanova et al., Ultrasonic diagnosis at the treatment of renal cell..., RAD Conf. Proc., vol. 4, 2020, 167-172

magnetic resonance imaging (MRI) were the methods for the comparison. All the patients were operated with subsequent histological verification. The US of IVC was performed intraoperatively. Transesophageal Echocardiography was performed if the thrombus was suspected of spreading into the right atrium.

\section{RESULTS AND DISCUSSION}

The level of thrombus spreading, the extent of its fixation and ingrowth inside the vascular wall, its structure and vascularization are of major importance for the planning of operation technique and predicting treatment outcomes. In some cases, especially if the thrombus is abundantly vascularized, ligation of the renal artery on the site of defeat leads to its significant retraction, which changes the further tactics of surgical intervention.

\section{1. Evaluation of the tumor extension}

The cases were ranged into the groups according to the Mayo Clinic Classification: $0-8$ (19.5\%) of patients; I - 11 (26.8\%); II - 8 (19.5\%); III - 10 (24.4\%); IV - 4 (9.8\%) [13]. Tumor of a single kidney complicated with tumor thrombosis of veins is revealed in 5 patients, 3 of them had undergone nephrectomy of a contralateral kidney for RCC several years before. Tumor thrombosis combined with metastasis in 26 (63.4\%) of cases. The target organs for metastasizing were lung - 14; liver - 10; adrenal gland - 4; lymph nodes - 10; pancreas - 1; diaphragm - 1, bone - 3, stomach - 1. Metastases in one organ were in 16 patients; in two - in 3; in three - in 6, in four - in 1 .

\subsection{Evaluation of the thrombus fixation and ingrowth inside the vascular wall}

The main benchmark of IVC invasion is the presence of a tumor on both sides of the vein wall. Another feasible diagnostic sign is a complete occlusion of the lumen of the vein and its enlargement [15]. Nevertheless, a minor invasion of the vein wall with a fixation of the thrombus to the vein wall is also possible, and this circumstance may limit the reduction of the tumor thrombus in size after the renal artery clamping [16].

J.Y. Wu et al. showed that a tumor thrombus invasion into IVC wall can be suspected according to the MRI data if the length of the thrombus is more than $7.91 \pm 3.59 \mathrm{~cm}$, there are some signs of complete occlusion of IVC lumen, the thrombus edges are uneven, the thrombus contacts with IVC wall, and the signal from the low-intensity vessel wall is altered [17]. L.C. Adams et al attempted to identify the reliable MRI signs and distinction between invasive and noninvasive IVC tumor thrombi. However, the authors did not manage to do this, because of a large number of false-positive results [18].

US tends to be more effective in the evaluation of pre- and intraoperative situation. Possible US signs of tumor invasion into the wall of IVC are the thrombus contact with the wall of IVC, thrombus occlusion of IVC lumen; local enhancement of blood flow in the thrombus at the site of the contact with the wall; changes of echogenicity, structure and thickness of the wall at the site of contact with the thrombus; nondisplacement of the thrombus relative to IVC wall during the forced breath and polyposition study; apparent invasion of IVC wall with the spread of tumor masses beyond it. One of the main criteria the thrombus is not fixed to IVC wall is its mobility and the presence of a color- and/or energy-mapped lumen between the thrombus and the vein wall (Fig. 1).

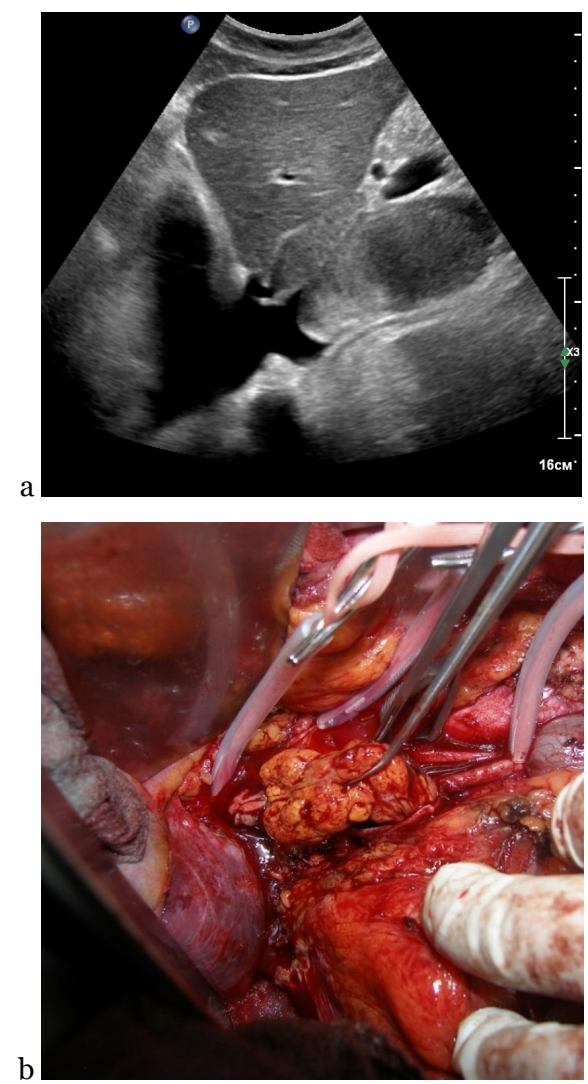

Figure 1. Mobile tumor thrombus reaching the suprahepatic part of IVC: $a$ - Ultrasound in B-mode; b - the same thrombus, extracted from the dissected IVC

We should emphasize, that if the thrombus is fixed to the wall of IVC or there is any minor invasion, it is difficult to get the static MDCT or MRI scan. In this cases US allows to assess the possible displacement of tumor masses, which makes this method of diagnostics the top priority.

\subsection{Evaluation of the thrombus structure}

One of the main features of the tumor thrombus is its developed network of neoplastic (tumor) vessels, that can be confirmed during preoperative examination according to the radiological methods, unlike hemorrhagic masses, which are avascular [19-21]. A densely vascularized tumor thrombus is clearly verified by the US. It is a homogeneous solid mass in the lumen of the vein, which has vessels in its structure of various degrees of severity (Fig. 2). 
We compared the results of preoperative US, intraoperative situation, macro- and microscopic examination of the removed thrombus, and managed to form an opinion on the risk of the thrombus fragmentation during the operation (Fig. 3). It is possible to assume the risk of the thrombus fragmentation with high probability based on the number of unfavourable factors: the large diameter of the thrombus, the length of the thrombus part which is above the diaphragm in IVC lumen; the way the thrombus connects with the wall of IVC; weak or irregular accumulation of the contrast agent by the tissue of the thrombus with contrast enhancement, absence of vessels in the structure of the thrombus, and the thrombus extension to the contralateral renal and/or hepatic veins and/or into the right atrium.
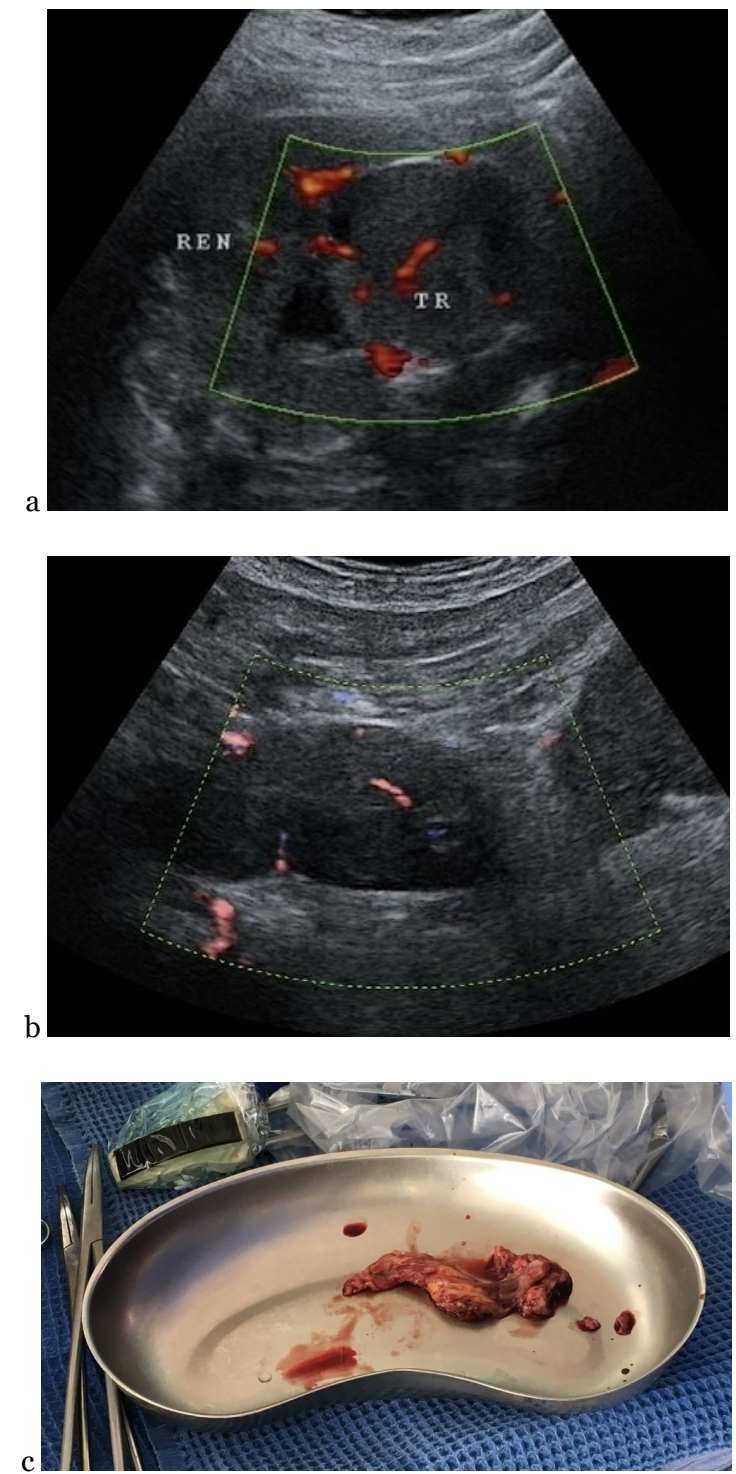

Figure 2. A densely vascularized tumor thrombus in Power Doppler Imaging: $\mathrm{a}$ - in the renal hilum; $\mathrm{b}$ - in IVC lumen; $\mathrm{c}$ - the macroscopic view of the tumor thrombus
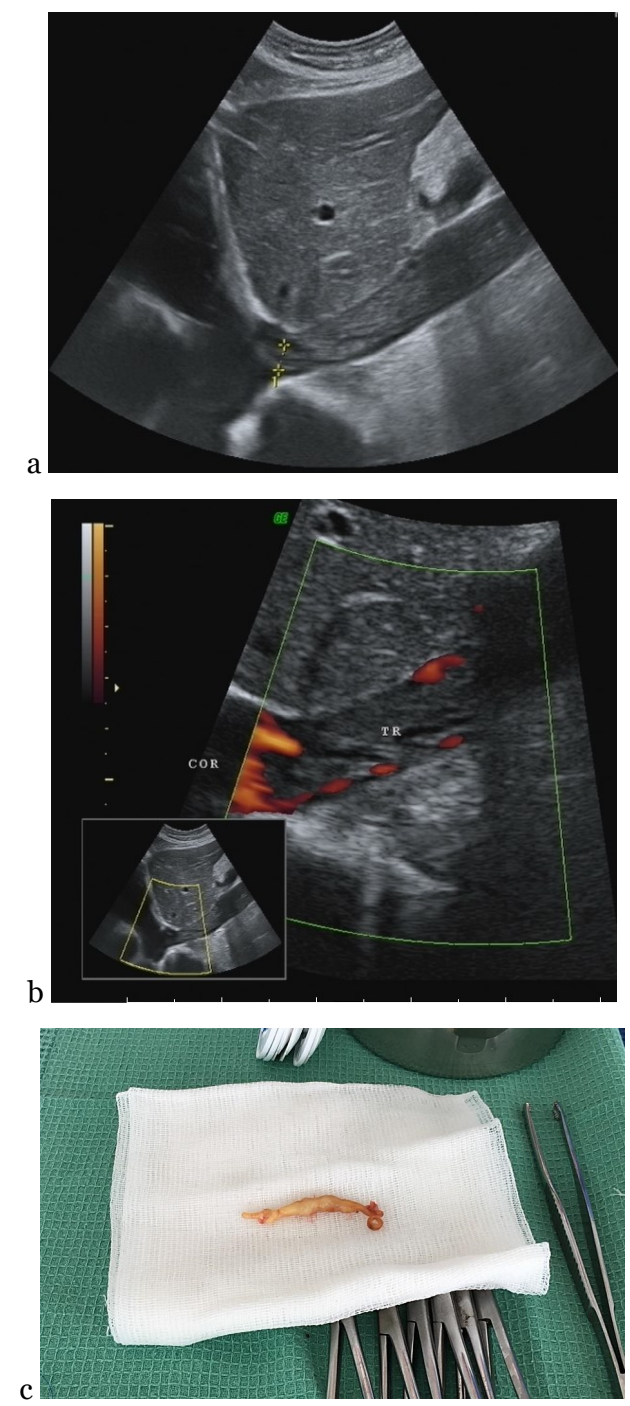

Figure 3. An avascular loose tumor thrombus of IVC spreading to the right atrium: a - head of tumor thrombus prolapsing from the IVC to the right atrium is marked,

B-mode; $b$ - thrombus at the level of the suprahepatic segment, Power Doppler Imaging; $\mathrm{c}$ - thrombus in the right atrium, four-chamber position in Transesophageal

Echocardiography; $d$ - macroscopic view of the thrombus head

US provides more sensitive qualitative data with an assessment of the dynamics of accumulation in real time without any radiation load when comparing data on the tumor thrombus contrasting with the results of MDCT and MRI with contrast enhancement. An algorithm for evaluating a tumor thrombus during US was developed based on the analysis of data from patients with RCC with renal and/or IVC tumor invasion:

\section{I stage (preoperatively):}

$\checkmark$ If a central kidney tumor localization is detected, especially if there is an involvement of the renal sinus, the lumen of the renal vein is evaluated for the possible presence of tumor thrombotic masses; 
Yu.A. Stepanova et al., Ultrasonic diagnosis at the treatment of renal cell..., RAD Conf. Proc., vol. 4, 2020, 167-172

$\checkmark$ If any tumor thrombotic masses are detected, we should evaluate the level of the thrombus extension:

- when the thrombus is detected in IVC, its lumen is evaluated throughout to determine the extent of the lesion, and the level of localization of the thrombus head is clearly recorded (it should be noted especially if it is not one);

- if the thrombus spreads up to the level of the diaphragm, it is evaluated whether the mass prolapsing into the heart cavity;

$\checkmark$ We should note displacement or non-displacement of the thrombus head relative to IVC wall, and the sites of fixation if it's possible, and also the head flotation during the forced breath and polyposition study;

$\checkmark$ We should evaluate the thrombus structure and its degree of vascularization.

\section{II stage (intraoperatively):}

$\checkmark$ We should estimate the localization of the thrombus head relatively to the nearby anatomical structures (in $\mathrm{mm}$ ) (for example, $17.0 \mathrm{~mm}$ below the level of the diaphragm) after IVC isolation:

- Transesophageal Echocardiography should be performed if the thrombus is suspected of spreading into the right atrium;

$\checkmark$ We should also estimate the localization of the thrombus head relatively to the anatomical structures determined before - after clamping of the renal arteries and veins, noting, whether there is any displacement as a result of blood flow reduction and by how much.

\subsection{Anaesthetic approach}

If the localization of the tumor thrombus is low, it is possible to accelerate the implementation of surgical intervention. Anyway, there is a high risk of intraoperative massive blood loss, development of acute renal injury in the intra- and postoperative period. The patients with RCC complicated by a highly localized tumor thrombus, even without severe concomitant pathology, are those with an extremely high risk of complications in the perioperative period (class IV according to ASA classification), have an expressed intoxication syndrome, violations of the hemostatic system, protein metabolism, waterelectrolyte and acid-base balance. Regardless we "compensate" the state of these patients as much as possible for all systems before the operation; there is still a high risk of intraoperative development of acute coronary syndrome, cardiac arrhythmias, pulmonary embolism, and massive blood loss. It is often necessary to use artificial blood circulation, which requires specialized hospital equipment and the skills of an anesthesiologist. In the postoperative period, there is also an extremely high risk of acute renal injury.

\subsection{Surgical treatment}

The US is very important for the determination of the operation volume. When a tumor thrombus spread into the lumen of IVC, regardless of its length, nephrectomy with thrombectomy from IVC (in 29 patients) was performed, which was combined with resection of IVC in the presence of ingrowth of the thrombus into the venous wall (in 19 patients). With a thrombus of $\mathrm{O}$ group according to the Mayo classification, 4 patients underwent radical nephrectomy ( 2 of them due to relapse after previous kidney resection). A distinctive feature of operations performed in group III patients was vascular isolation of the liver, in group IV - the presence of a cardiopulmonary bypass device and the presence of a team of cardiac surgeons.

Due to the use of the patient management algorithm developed by us, 3 (75\%) of 4 patients in group IV avoided cardiologic stage of the operation, since intraoperative US revealed a reduction in the tumor thrombus and the location of its head below the diaphragm level. Patients with a single kidney underwent kidney resection: isolated - 3 patients, in combination with thrombectomy from IVC - 2 . Radiofrequency ablation of the remaining foci was performed as the second stage of surgical treatment for a patient with primary multiple synchronous RCC due to the severity of the condition (the first stage is nephrectomy with thrombectomy from IVC).

\section{DISCUSSION}

The sensitivity of MDCT in determination of IVC thrombosis length is $85 \%$, and its specificity is $98 \%$. Correct assessment of unaltered renal veins is performed in approximately $96 \%$ of cases [22]. However, it is almost impossible to make a clear decision about the nature of thrombosis based on MDCT data. The only sign of tumor thrombosis may be the detection of contrasting vessels in the thickness of the tumor itself and in the thrombosed area, but they are often difficult to recognize [23]. Nowadays MRI is the method of choice in the diagnosis of IVC thrombus and determining its upper limit (MR venography techniques, both native and with bolus administration of gadolinium-containing drugs) [24]. We should also note the disadvantages of magnetic resonance angiography in the diagnosis of supradiaphragmatic thrombosis, which is associated with motor artifacts due to heart and respiratory contraction [25]. MRI may also be restricted if the patient has metal implants. At the same time, according to a number of authors, US has much more diagnostic capabilities in detecting IVC thrombosis in comparison with MDCT: the sensitivity of this method reaches $100 \%[19,26]$. According to a study by A. Khan et al., Doppler US also prevails over MSCT in thrombi detecting in IVC [14].

The analysis of the patients data treated at the A.V. Vishnevsky National Medical Research Center of Surgery, showed a high efficiency of ultrasound in assessing IVC tumor thrombosis. Unfortunately, in this situation, it is rather difficult to carry out a statistical analysis due to the fact that despite the ranking of the trombosis according to the Mayo classification, almost every patient has individual characteristics of the lesion that require a personalized approach. Based on our own experience in treating such patients, an algorithm for their examination and accordingly a protocol for preoperative examination (Table 1) was 
Yu.A. Stepanova et al., Ultrasonic diagnosis at the treatment of renal cell..., RAD Conf. Proc., vol. 4, 2020, 167-172

developed. Intraoperative assessment is performed before and after the ligation of the renal artery in order to assess the possible reduction of the thrombus in size after reduction of blood flow, as well as after thrombectomy. Also, additional assessment points related to the intraoperative situation are possible. The results of our study indicate that the US effectiveness is especially high in specialized clinics that deal with oncourology and have modern diagnostic US equipment with a wide range of modalities. However, we should remember that MDCT and/or MRI can provide more accurate information about the level of spread of a tumor thrombus than IVC in case of limited echographic imaging due to the patient's constitutional characteristics or poor preparation for the study.

Table 1. Protocol for the assessment of tumor thrombus in a patient with RCC according to ultrasound (preoperative assessment)

\begin{tabular}{|c|c|c|c|}
\hline \multicolumn{2}{|c|}{ Characteristics } & Rating & $\begin{array}{c}\text { Additional } \\
\text { descriptive } \\
\text { information (if }\end{array}$ \\
\hline \multirow{2}{*}{ Tumor } & $\begin{array}{l}\text { tumor central } \\
\text { localization }\end{array}$ & yes/no & \\
\hline & $\begin{array}{l}\text { sinus } \\
\text { involvement }\end{array}$ & yes/no & \\
\hline \multicolumn{4}{|c|}{ Thrombus localization } \\
\hline Renal vein & $\begin{array}{l}\text { thrombotic } \\
\text { masses }\end{array}$ & yes/no & \\
\hline \multirow{3}{*}{$\begin{array}{l}\text { Inferior } \\
\text { vena cava }\end{array}$} & $\begin{array}{l}\text { thrombotic } \\
\text { masses }\end{array}$ & yes/no & \\
\hline & $\begin{array}{l}\text { thrombus head } \\
\text { localization, } \\
\text { according to the } \\
\text { Mayo } \\
\text { classification } \\
\text { (Blute M.L., } \\
\text { Leibovich B.C., } \\
\text { Lohse C.M. et } \\
\text { al., 2004) }\end{array}$ & $\begin{array}{l}\text { indicate } \\
\text { level }\end{array}$ & \\
\hline & $\begin{array}{l}\text { number of } \\
\text { thrombus } \\
\text { heads }\end{array}$ & & \\
\hline \multirow{2}{*}{ Heart } & $\begin{array}{l}\text { is there spread } \\
\text { to the heart } \\
\text { cavity }\end{array}$ & yes/no & \\
\hline & $\begin{array}{l}\text { which cavities } \\
\text { are involved, } \\
\text { length in } \mathrm{mm}\end{array}$ & & \\
\hline \multicolumn{4}{|c|}{ Thrombus assessment } \\
\hline \multicolumn{2}{|c|}{$\begin{array}{l}\text { forced breathing } \\
\text { displacement }\end{array}$} & yes/no & \\
\hline \multicolumn{2}{|c|}{ fixation sites } & $\begin{array}{l}\text { yes/no, } \\
\text { indicate } \\
\text { level }\end{array}$ & \\
\hline \multicolumn{2}{|c|}{ thrombus head flotation } & yes/no & \\
\hline \multirow{2}{*}{\multicolumn{2}{|c|}{$\begin{array}{l}\text { structure } \\
\text { vascularization }\end{array}$}} & & \\
\hline & & & \\
\hline
\end{tabular}

\section{CONCLUSION}

Radiological methods play a crucial role in the determination of treatment tactics, the scope of surgery, as well as dynamic control. The algorithm of US allows us to determine the level of spread, structure and possible invasion of a tumor thrombus most accurately, thereby determining the volume of surgical intervention and, in some cases, leading to its reduction. Various modalities of the US allow us to answer the above questions, both preoperatively and during the surgery. It is also important that US methods don 't require any radiation load and nephrotoxic contrast agent, which is of special significance for the patients with RCC. Moreover, it is possible to repeat the study several times and evaluate it in real time. This study is also cheaper than MSCT and MRI.

\section{REFERENCES}

1. В.Н. Лесовой, Д.В. Щукин, Ю.А. Илюхин, Проблемы классификации внутривенозного распространения почечно-клеточного рака, Международный медицинский журнал, 2011, 4, стр. 65-68.

(V.N. Lesovoy, D.V. Schukin, Yu.A. Ilyuhin, "Problems of classification of intravenous spread of renal cell carcinoma," International Medical Journal, vol. 4, pp. 65-68, 2011).

2. M. Al Otaibi, S. Tanguay, "Locally advanced renal cell carcinoma,” Can. Urol. Assoc J., vol. 1, no. 2, S55-S61, Jun. 2007. http://doi.org/10.5489/cuaj.68

3. M. Tanaka, K. Fujimoto, E. Okajima, N. Tanaka, K. Yoshida, Y. Hirao, "Prognostic factors of renal cell carcinoma with extension into inferior vena cava," Int. J. Urol. vol. 15, no. 5, pp. 394-398, May 2008. http://doi.org/10.1111/j.1442-2042.2008.02017.x

4. А. Д. Каприн, В. В. Старинский, Г. В. Петрова, “Злокачественные новообразования в России в 2017 году (заболеваемость и смертность),” М.: МНИОИ им. П.А. Герцена, 2018; 250 с.

(A. D. Kaprin, V. V. Starinskiy, G. V. Petrova, Malignant neoplasms in Russia in 2017 (morbidity and mortality), M.: MNIOI im. P. A. Gertsena, 2018, 250 pages.)

Retrieved from:

https://glavonco.ru/cancer register/\%Do\%97\%Do\%B O\%Do\%B1\%Do\%BE\%Do\%BB 2018 \%Do\%AD\%Do\% BB\%Do\%B5\%D0\%BA\%D1\%82\%D1\%80.pdf Retrieved on: September 27, 2020

5. J. I. Martínez-Salamanca et al., "Lessons learned from the International Renal Cell Carcinoma-Venous Thrombus Consortium (IRCC-VTC)," Curr. Urol. Rep., vol. 15, no. 5, article no. 404, May 2014. http://doi.org/10.1007/s11934-014-0404-7

6. В.Б. Матвеев, Хирургическое лечение осложненного венозной инвазией и метастатического рака почки. Дисс. ... докт. мед. наук. М., 2002; 198 с.

(V. B. Matveev, "Surgical treatment of complicated venous invasion and metastatic kidney cancer," $\mathrm{PhD}$ dissertation, 2002, 198 pages.)

7. Клиническая онкоурология. Под ред. проф. Б.П. Матвеева. М.: Вердана, 2003; 717 с (Clinical oncourology, B. P. Matveev, Ed., M.: Verdana, 2003, 717 pages.)

8. М. И. Давыдов и другие, "Хирургическое лечение рака почки, осложненного опухолевым венозным тромбозом III-IV уровней," Онкоурология, vol. 4, no. 12, pp. 21-34, 2016.

(M. I. Davydov et al., "Surgical treatment of kidney cancer complicated by neoplastic venous thrombosis of III-IV levels," Oncourology, vol. 4, no. 12, pp. 21-34, 2016.

http://doi.org/10.17650/1726-9776-2016-12-4-21-34

9. N. K. Bissada et al., "Long-term experience with management of renal cell carcinoma involving the inferior vena cava," Urology, vol. 61, no. 1, pp. 89-92, Jan. 2003.

http://doi.org/10.1016/s0090-4295(02)02119-2 
Yu.A. Stepanova et al., Ultrasonic diagnosis at the treatment of renal cell..., RAD Conf. Proc., vol. 4, 2020, 167-172

10. M. L. Blute, S. A. Boorjian, B. C. Leibovich, C. M. Lohse, I. Frank, R. J. Karnes, "Results of inferior vena caval interruption by greenfield filter, ligation or resection during radical nephrectomy and tumour thrombectomy," J. Urol., vol. 178, pp. 440-445, 2007. http://doi.org/10.1016/j.juro.2007.03.121

11. R. Bertini et al., "Impact of venous tumour thrombus consistency (solid vs friable) on cancer-specific survival in patients with renal cell carcinoma," Eur. Urol., vol. 6o, no. 2, pp. 358-365, Aug. 2011. http://doi.org/10.1016/j.eururo.2011.05.029

12. V. L. Weiss et al., "Prognostic significance of venous tumour thrombus consistency in patients with renal cell carcinoma (RCC)," BJU Int., vol. 113, no. 2, pp. 209-217, Feb. 2014. http://doi.org/10.1111/bju.12322

13. M. L. Blute, B. C. Leibovich, C. M. Lohse, J. C. Cheville, H. Zincke, "The Mayo Clinic experience with surgical management, complications and outcome for patients with renal cell carcinoma and venous tumour thrombus," BJU Int., vol. 94, no. 1, pp. 33-41, Jul. 2004.

http://doi.org/10.1111/j.1464-410X.2004.04897.x

14. S. P. Psutka et al., "Clinical and radiographic predictors of the need for inferior vena cava resection during nephrectomy for patients with renal cell carcinoma and caval tumour thrombus," BJU Int., vol. 116, no. 3, pp. 388-396, Sep. 2015. http://doi.org/10.1111/bju.13005

15. K. B. Quencer, T. Friedman, R. Sheth, R. Oklu, "Tumour thrombus: incidence, imaging, prognosis and treatment," Cardiovasc Diagn Ther., vol. 7, no. 3, S165-S177, Dec. 2017. http://doi.org/10.21037/cdt.2017.09.16

16. Н.Б. Вихрова, Б.И. Долгушин, В.О. Панов, В.Б. Матвеев, Н.Л. Шимановский, Е.К. Дворова, “Лучевые методы диагностики в определении структуры опухолевого тромба в нижней полой вене при раке почки," Онкоурология, vol. 11, no. 3, pp. 40-45, 2015

(N. B. Vihrova, B. I. Dolgushin, V. O. Panov, V. B. Matveev, N. L. Shimanovsky, E. K. Dvorova, "Radiology diagnostic methods in determining the structure of a tumor thrombus in the inferior vena cava in kidney cancer," Oncourology, vol. 11, no. 3, pp. 40-45, 2015.) http://doi.org/10.17650/1726-9776-2015-11-3-40-45

17. J. Y. Wu et al., "Evaluating inferior vena cava wall invasion in renal cell carcinoma tumour thrombus with MRI," Beijing Da Xue Xue Bao Yi Xue Ban., vol. 51, no. 4, pp. 673-677, Aug. 2019. http://doi.org/10.19723/j.issn.1671-167X.2019.04.013

18. L. C. Adams et al., "Renal cell carcinoma with venous extension: prediction of inferior vena cava wall invasion by MRI," Cancer Imaging, vol. 18, no. 1, article no. 17, May 2018.

http://doi.org/10.1186/s40644-018-0150-Z
PMID: 29724245

19. K. Sorrell, S. Harris, J. Hanna, B. Oglesby, "Renal Vein and Inferior Vena Cava Tumour Thrombus: Presentation and Mapping of Venous Extension with Color Duplex Ultrasound," The Journal for Vascular Ultrasound, vol. 30, no. 1, pp. 9-15, 2006. http://doi.org/10.1177/154431670603000101

20. D. C. Vergho, A. Loeser, A. Kocot, M. Spahn, H. Riedmiller, "Tumour thrombus of inferior vena cava in patients with renal cell carcinoma - clinical and oncological outcome of 50 patients after surgery," BMC Res. Notes, vol. 5, p. 5, Jun. 2012. http://doi.org/10.1186/1756-0500-5-264

21. S. P. Psutka, B. C. Leibovich, "Management of inferior vena cava tumour thrombus in locally advanced renal cell carcinoma," Ther. Adv. Urol., vol. 7, no. 4, pp. 216-229, Aug. 2015. http://doi.org/10.1177/1756287215576443

22. T. Davidson, O. Goitein, A. Avigdor, S. T. Zwas, E. Goshen, "18F- FDG-PET/CT for the diagnosis of tumour thrombosis," Isr. Med. Assoc. J., vol. 11, no. 2, pp. 69-73, Feb. 2009.

23. F. C. Sampson, S. W. Goodacre, S. M. Thomas, E. J. van Beek, "The accuracy of MRI in diagnosis of suspected deep vein thrombosis: systematic review and meta-analysis," Eur. Radiol., vol. 17, no. 1, pp. 175-181, Jan. 2007. http://doi.org/10.1007/s00330-006-0178-5

24. Ю.Г. Аляев, В.Е. Синицин, Н.А. Григорьев, Магнитно-резонансная томография в урологии. М.: Практическая медицина. 2005; 272 c.

(Yu. G Alyaev., V. E. Sinitsin, N. A. Grigorev, Magnetic resonance imaging in urology. - M.: Practical medicine, 2005; 272 pages.)

25. Н.Б. Вихрова, Лучевые методы диагностики в оценке распространенности и структуры опухолевого тромба в нижней полой вене у больных раком почки. Российский онкологический журнал. 2014; 2: 51-56.

(N. B. Vihrova, "Radiology diagnostic methods in assessing the prevalence and structure of tumor thrombus in the inferior vena cava in patients with kidney cancer," Russian Journal of Oncology, vol. 2, pp. 51-56, 2014.)

Retrieved from:

https://cyberleninka.ru/article/n/luchevye-metodydiagnostiki-v-otsenke-rasprostranennosti-i-strukturyopuholevogo-tromba-v-nizhney-poloy-vene-u-bolnyhrakom-pochki

Retrieved on: September 20, 2020

26. A. R. Khan, K. Anwar, N. Fatima, S. F. Khan, "Comparison of CT scan and colour flow Doppler ultrasound in detecting venous tumour thrombous in renal cell carcinoma," J. Ayub. Med. Coll. Abbottabad., vol. 20, no. 3, pp. 47-50, Jul-Sep. 2008. 